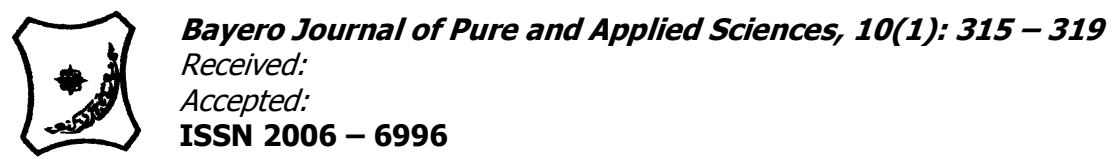

\title{
ENVIRONMENTAL IMPACTS OF CRUDE OIL SPILLAGES ON WATER IN IBENO LOCAL GOVERNMENT AREA OF AKWA IBOM STATE, NIGERIA
}

\author{
Ndeh, E. S., Okafor, J. O., Akpan, G. U. and Olutoye, M. A. \\ Department of Chemical Engineering, School of Engineering and Engineering Technology, Federal University of \\ Technology, Minna, Niger State, Nigeria. \\ ediudy24@gmail.com
}

\begin{abstract}
Crude oil spillage has been identified to be a regular occurrence in Upenekang village in Ibeno Local Government Area of Akwa Ibom State, Nigeria. This study has been carried out to find out the effect of crude oil spill on stream water and the environmental impact it has on the area. Using water samples obtained at varying distances from the spill site, the effects of the crude oil spill on the surface and underground stream water at the spill site were investigated by testing for the presence as well as the concentrations of toxic heavy metal pollutants. Analyses were also carried out for water conductivity, $\mathrm{pH}$, temperature, hardness, total solids, total dissolved solids, turbidity, suspended solids, dissolved oxygen, carbon dioxide, COD, BOD, THC, sodium, potassium, magnesium, calcium, sulphate, nitrate, iron, copper, lead, chromium and cadmium concentrations using standard methods. The $\mathrm{pH}$ of all the samples of both the surface and underground stream water obtained at the spill site were observed to be acidic with very low dissolved oxygen, low COD, low BOD, high hydrocarbon content, high total dissolved solids, high water hardness and high toxic heavy metal concentrations (iron, copper, lead, chromium and cadmium) investigated for, all above admissible concentrations by World Health Organization's standards. A one-way ANOVA showed that there is no significant influence of distance away from spill on the level of heavy metals in the water samples collected in the study area.
\end{abstract}

Keywords: Crude oil spill, Upenekang, Water, WHO, ANOVA.

\section{INTRODUCTION}

The threat to human and aquatic lives posed by crude oil spillages cannot be overemphasized. Oil spillage is the release of liquid petroleum hydrocarbon into the environment due to human activities, and is a form of pollution. The term often refers to marine oil spills, where oil is released into the ocean or coastal waters. Oil spills include releases of crude oil from tankers, offshore platforms, drilling rigs and wells, as well as spills of refined petroleum products (such as gasoline, diesel) and their by-products, and heavier fuels used by large ships such as bunker fuel, or the spill of any oily white substance refuse or waste oil. Spills may take months or even years to clean up. Oil also enters the marine environment from natural oil seeps. Public attention and regulation has tended to focus most sharply on seagoing oil tankers. Oil spillage is one of the greatest environmental problems. Oil communities have been at the receiving end of this environmental problem. The problems have generated a lot of concerns within the three tiers of government especially in oil producing states. Oil spillage is one of the contentious issues facing the government, the oil industry and the host communities of the Niger Delta region which Ibeno Local Government Area is one of them. Hydrocarbons are chemical compounds composed of the elements hydrogen and carbon. This includes substances that are commonly thought of as oils, such as crude oil and refined petroleum products, but it also includes animal fats, vegetable oils, and other non-petroleum oils. Crude oil spills are mainly caused by equipment failure, operational errors, and leaks from obsolete pipes or willful damage. Many of the oil facilities and operations are located within sensitive habitats - including areas vital to fish breeding, sea turtle nesting, mangroves and rainforests. Also drinking water sources are polluted, thus potable water have become very scarce. The presence of oil spillages causes a major impact on the riverine ecosystem and is a likely determinant factor of the poor water quality in oil producing communities like Ibeno (Akoroda, 2000).

Stagnant water bodies cause the oil to remain in the environment for long, resulting in prolonged exposure of the plants and animals (Chindah, 2000). In the case of flowing streams and obtaining potable water, the oil is transported along with the flow of the stream, thereby increasing its area of contamination. Although, there is paucity of research on the effect of hydrocarbon pollution on declining fishery resources, some studies have examined the specific impact of oil activities on aquatic species. One of such studies by Osuntokun (1999) noted that the pollution impact of oil spills affects both water and land. This causes unquantifiable ecological devastation, destruction of marine life and consequently leads to socio-economic paralysis. 
A research study carried out by Magini (2006), on the effects of oil spillage on water quality/ management in Emadadja, Udu local government area, Delta State, Nigeria showed that the water quality was polluted due to the presence of toxic heavy metals. Other studies by the Niger Delta Environmental Survey have discovered that the toxic properties of hydrocarbon can lead to an immediate death of aquatic life and seabirds, lobsters, fish and crab. Those that survive the spill would have ingested ample oil, which would make them taste oily when eaten. The medium and long term effect is that the means of sustenance of these communities become paralyzed. This implies that the contamination of rivers and creeks that form sources of water to the host communities becomes contaminated and unsuitable for human consumption. From the environmental point of view, the parameters to characterize the soil and sediment will depend on organic contaminants and the metals, especially the heavy metal content and their species in the soil (Miguel and Salvador, 1998).

\section{MATERIALS AND METHODS}

\section{Collection of Samples}

Surface and underground stream water samples were obtained at $100 \mathrm{~m}$ intervals from each sample point at the spill site. Stream water samples obtained outside the spill site served as the control samples. Borehole water sample was also obtained from the study area. All the water samples obtained were taken for laboratory analysis using standard methods.

\section{Determination of Turbidity}

The electrode of the turbidity meter was introduced into $50 \mathrm{ml}$ of each water sample and the turbidity readings were taken (American Water Works Association, 1980).

\section{Determination of Chemical Oxygen Demand (COD)}

A volume of $50 \mathrm{ml}$ of each water sample was measured into different conical flasks.5ml of dilute $\mathrm{H}_{2} \mathrm{SO}_{4}$ was added and the solution was quickly transferred to a steam bath to boil. Then $15 \mathrm{ml}$ of $0.01 \mathrm{M} \mathrm{H}_{2} \mathrm{C}_{2} \mathrm{O}_{4}$ was added followed by the drop-wise addition of $\mathrm{KMnO}_{4}(0.01 \mathrm{M})$ from the burette until the solution turned pink (A.O.A.C, 1984).

Determination of Heavy Metals (iron, copper, lead, chromium and cadmium)

A volume of $100 \mathrm{ml}$ of the water samples were measured into a $250 \mathrm{ml}$ beaker. $10 \mathrm{ml}$ of $\mathrm{HCl}$ were measured into the beakers followed by $30 \mathrm{ml}$ of nitric acid and were heated on the hot plate for 10-15 minutes at a temperature between $65-70^{\circ} \mathrm{C}$ to digest. After the digestion, the samples were allowed to cool and were filtered using funnel and filter paper into a beaker and were made up to $100 \mathrm{ml}$ ready for analysis. The digested solutions were analyzed for the presence of iron, copper, lead, chromium and cadmium using atomic absorption spectrophotometer (Unicam 939 AAS) with different lamps in position (Ademoroti, 1996).

\section{Statistical Analysis}

Results were compared by analysis of variance (ANOVA) at 0.05 level of significance as described by Oyeka, (1996).

\section{RESULTS AND DISCUSSION}

The physico-chemical characteristics of the surface stream water samples obtained at $100 \mathrm{~m}, 200,300$, 400,500 and $600 \mathrm{~m}$ away from spill are shown in Table 1 and the $\mathrm{pH}$ values of the surface water samples obtained at the spill site were observed to be $4.8,6.2,5.8,5.6$ and 5.9

respectively indicating acidity of the water samples as compared to 6.5 of World Health Organization's standard while in the control sample (outside the spill site) is 6.6 indicating non-contamination of the water sample. Toxic heavy metals like iron, copper, lead, chromium and cadmium were also tested concentrations were observed to be high when present as compared to the World Health Organization's standard. The sources of these heavy metals are most likely to be the crude oil spills on water bodies especially if one takes into consideration the chemical composition of crude oil. Heavy metals in drinking water samples are related with chronic diseases in humans such as dizziness, nausea, shortness of breath, headaches, fatigue in coordination, as well as irritation of the eyes, which the people of Ibeno LGA have complained of (Magini, 2006).

The results of some vital tests of the water samples in terms of turbidity, conductivity, hardness, total solids, total dissolved solids, calcium, magnesium concentrations, chemical oxygen demand (COD) and biological oxygen demand (BOD) were carried out. The chemical oxygen demand values were observed to be 339, 289, 300, 256, 196 and $194 \mathrm{mg} / \mathrm{L}$ at distances 100, 200, 300, 400, 500 and $600 \mathrm{~m}$ respectively. These values were seen to be worrisome when compared to the World Health Organization's standard. High chemical oxygen demand is an indication of increased biological activities and rate of chemical reaction in the water due to the crude oil spill on the water (Ademoroti, 1986). Higher values of calcium and magnesium beyond W.H.O limit were observed which is an indication of high water hardness in the characterized water samples. Therefore, these polluted waters will not be suitable for consumption by human and aquatic lives (Magini, 2006).

The physico-chemical characteristics of the underground stream water samples obtained at 100 , $200,300,400,500$ and $600 \mathrm{~m}$ away from spill are presented on Table 2 . The $\mathrm{pH}$ values of the underground samples were observed to be 5.4, 5.6, $6.1,4.9,5.8$ and 6.1 respectively again indicating acidity of the water samples which can be toxic to humans and aquatic lives. Toxic heavy metals like iron, copper, lead, chromium and cadmium were in high concentrations when compared to the World Health Organization's permissible limit. This has rendered underground water in these areas unusable because such water is capable of causing health defects in both plant and animals (Magini, 2006). Oil spill is associated with low dissolved oxygen concentration, increased biochemical oxygen demand, increased water temperature and acidity of the water as reported by Enujiugha and Nwanna, (2004). 
Oil spill on water increases respiration rates of aquatic organisms leading to increased oxygen consumption and increased decomposition of organic matter which leads to low dissolved oxygen in the water. It was further observed that increased temperature decreases the solubility of gases (especially oxygen) in water which is what has been observed in this study. The lower dissolved oxygen (DO) values in the study area imply that the water is more polluted. DO is essential to all forms of aquatic life including the organisms that break down man-made pollutants. Oxygen is soluble in water. Oxygen tends to be less soluble as temperature increases. In general, the concentration of dissolved oxygen will be the result of biological activity. In natural waters, man-made contamination or natural organic material will be consumed by microorganisms. As this microbial activity increases, oxygen will be consumed out of the water by the organisms to facilitate their digestion process. The water that is near the sediment will be depleted of oxygen for this reason. The oxygen will be consumed and the water will become anaerobic. The generally accepted indicators of water quality are dissolved oxygen (DO) and the biochemical oxygen demand according to Damaskos and Papadopoulos (1983).

Table 3 shows that the calculated F-value of (0.31) was obtained after testing for significance at 0.05 alpha level with 6 and 150 degrees of freedom. The calculated F-value (0.31) was less than the table Fvalue (2.09). Hence, the effect of distance on water pollution is not significant.

Again, table 4 shows that the calculated F-value of (0.21) was obtained at 0.05 alpha level of significance with 6 and 149 degrees of freedom. The calculated Fvalue 0.21 was less than the table F-value 2.09. Therefore, the result was statistically not significant.

Table 1: Physico- Chemical Characteristics of Surface Water Samples at Different Distances from the Site of Spill.

\begin{tabular}{|c|c|c|c|c|c|c|c|c|c|}
\hline $\mathbf{S / N}$ & PARAMETER & $100 \mathrm{~m}$ & $200 m$ & $300 m$ & $400 m$ & $500 m$ & $600 \mathrm{~m}$ & Control & $\begin{array}{c}\text { W.H.O. } \\
\text { STANDARD }\end{array}$ \\
\hline 1 & Temperature $\left({ }^{\circ} \mathrm{C}\right)$ & & & & & & & & \\
\hline & & 30.4 & 29.2 & 28.9 & 28.7 & 29.1 & 27.7 & 27.2 & 25 \\
\hline 2 & $\mathrm{pH}$ & 4.8 & 6.2 & 5.8 & 5.6 & 5.6 & 5.9 & 6.6 & $6.5-8.5$ \\
\hline 3 & $\begin{array}{l}\text { Turbidity } \\
\text { (NTU) }\end{array}$ & 15 & 13 & 12 & 13 & 10 & 11 & 6 & $<5$ \\
\hline 4 & $\begin{array}{l}\text { Conductivity } \\
(\mu \mathrm{s} / \mathrm{cm})\end{array}$ & 32.35 & 26.86 & 24.85 & 33.65 & 28.61 & 19.98 & 9.46 & 500 \\
\hline 5 & $\begin{array}{c}\text { Hardness } \\
\text { (mg/L) }\end{array}$ & 11.83 & 15.60 & 9.65 & 13.75 & 12.67 & 10.91 & 9.76 & 200 \\
\hline 6 & Total solids(mg/L) & 320 & 294 & 309 & 289 & 224 & 218 & 97.9 & 500 \\
\hline 7 & $\begin{array}{l}\text { Total dissolve } \\
\text { solids(mg/L) }\end{array}$ & 310 & 285 & 298 & 277 & 215 & 210 & 88.7 & 500 \\
\hline 8 & $\begin{array}{l}\text { Suspended } \\
\text { solids(mg/L) }\end{array}$ & 10 & 9 & 11 & 12 & 9 & 8 & 9 & 20 \\
\hline 9 & $\begin{array}{c}\text { Dissolved } \\
\text { oxygen }(\mathrm{mg} / \mathrm{L})\end{array}$ & 1.75 & 1.62 & 2.04 & 1.86 & 2.11 & 1.58 & 5.87 & 3 minimum \\
\hline 10 & $\begin{array}{c}\text { Carbon } \\
\text { dioxide }(\mathrm{mg} / \mathrm{L})\end{array}$ & 20.87 & 14.76 & 23.60 & 22.84 & 18.75 & 25.76 & 42.65 & 50 \\
\hline 11 & C.O.D(mg/L) & 339 & 289 & 300 & 256 & 196 & 194 & 107 & 125 \\
\hline 12 & B.O.D(mg/L) & 12.65 & 13.43 & 15.83 & 12.55 & 13.91 & 12.32 & 7.82 & 10 \\
\hline 13 & T.H.C(mg/L) & 1.25 & 1.12 & 0.08 & 0.13 & ND & ND & ND & 0.05 \\
\hline 14 & Sodium(mg/L) & 16.85 & 18.77 & 15.88 & 12.54 & 12.65 & 11.64 & 7.83 & 200 \\
\hline 15 & $\begin{array}{l}\text { Potassium } \\
\text { (mg/L) }\end{array}$ & 5.48 & 11.74 & 8.98 & 11.56 & 10.06 & 7.98 & 4.75 & 2 \\
\hline 16 & $\begin{array}{l}\text { Magnesium } \\
(\mathrm{mg} / \mathrm{L})\end{array}$ & 45.76 & 62.54 & 49.98 & 45.95 & 42.54 & 41.45 & 28.87 & 37 \\
\hline 17 & $\begin{array}{l}\text { Calcium } \\
\text { (mg/L) }\end{array}$ & 55.78 & 53.76 & 58.73 & 51.45 & 52.46 & 50.46 & 37.24 & 50 \\
\hline 18 & $\begin{array}{l}\text { Sulphate } \\
\text { (mg/L) }\end{array}$ & 26.45 & 19.76 & 29.87 & 24.65 & 18.87 & 26.11 & 10.86 & 500 \\
\hline 19 & Nitrate(mg/L) & 2.621 & 1.332 & 1.129 & 0.843 & 1.236 & 1.464 & 15.851 & 1.5 \\
\hline 20 & $\operatorname{Iron}(\mathrm{mg} / \mathrm{L})$ & 1.652 & 1.751 & 1.461 & 1.413 & 1.093 & 2.104 & 0.921 & 1.0 \\
\hline 21 & Copper(mg/L) & 1.741 & ND & 1.413 & 0.931 & 1.491 & 1.536 & I.0 & 1.0 \\
\hline 22 & $\operatorname{Lead}(\mathrm{mg} / \mathrm{L})$ & 1.419 & 0.721 & ND & 0.031 & 0.941 & 0.149 & 0.035 & 0.05 \\
\hline 23 & $\begin{array}{l}\text { Chromium } \\
(\mathrm{mg} / \mathrm{L})\end{array}$ & 0.415 & 0.541 & 0.941 & ND & 0.051 & 0.432 & ND & 0.05 \\
\hline 24 & $\begin{array}{l}\text { Cadmium } \\
(\mathrm{mg} / \mathrm{L})\end{array}$ & 0.145 & 0.145 & 0.143 & ND & ND & ND & ND & 0.01 \\
\hline
\end{tabular}


Bajopas Volume 10 Number 1 June, 2017

Table 2: Physico- Chemical Characteristics of Underground Water Samples at Different Distances from the Site of Spill.

\begin{tabular}{|c|c|c|c|c|c|c|c|c|c|}
\hline $\begin{array}{l}\mathbf{S} / \\
\mathbf{N}\end{array}$ & PARAMETER & $100 \mathrm{~m}$ & $200 m$ & $\begin{array}{c}300 \\
\mathbf{m}\end{array}$ & $\begin{array}{c}400 \\
\mathrm{~m}\end{array}$ & $\begin{array}{c}500 \\
\mathbf{m}\end{array}$ & $600 \mathrm{~m}$ & Control & $\begin{array}{c}\text { W.H.O. } \\
\text { STANDARD }\end{array}$ \\
\hline 1 & $\begin{array}{c}\text { Temperature } \\
\left({ }^{\circ} \mathrm{C}\right)\end{array}$ & 28.7 & 28.1 & 28.5 & 28.4 & 28.9 & 27.5 & 27.0 & 25 \\
\hline 2 & $\mathrm{pH}$ & 5.4 & 5.6 & 6.1 & 4.9 & 5.8 & 6.1 & 6.7 & $6.5-8.5$ \\
\hline 3 & $\begin{array}{l}\text { Turbidity } \\
\text { (NTU) }\end{array}$ & 13 & 10 & 14 & 9 & 11 & 9 & 7 & $<5$ \\
\hline 4 & $\begin{array}{l}\text { Conductivity } \\
(\mu \mathrm{s} / \mathrm{cm})\end{array}$ & 29.72 & 30.34 & 27.97 & 27.32 & 29.50 & 24.75 & 12.65 & 500 \\
\hline 5 & $\begin{array}{l}\text { Hardness } \\
(\mathrm{mg} / \mathrm{L})\end{array}$ & 14.55 & 11.51 & 11.87 & 11.84 & 10.52 & 16.12 & 10.54 & 200 \\
\hline 6 & $\begin{array}{c}\text { Total } \\
\text { solids(mg/L) }\end{array}$ & 248 & 284 & 284 & 266 & 214 & 217 & 102.8 & 500 \\
\hline 7 & $\begin{array}{l}\text { Total dissolve } \\
\text { solids(mg/L) }\end{array}$ & 240 & 276 & 275 & 255 & 207 & 208 & 92.8 & 500 \\
\hline 8 & $\begin{array}{l}\text { Suspended } \\
\text { solids(mg/L) }\end{array}$ & 8 & 8 & 9 & 11 & 7 & 9 & 10 & 20 \\
\hline 9 & $\begin{array}{c}\text { Dissolved } \\
\text { oxygen }(\mathrm{mg} / \mathrm{L})\end{array}$ & 2.68 & 2.08 & 1.85 & 2.08 & 1.83 & 1.88 & 8.35 & 3 minimum \\
\hline 10 & $\begin{array}{c}\text { Carbon } \\
\text { dioxide }(m g / L)\end{array}$ & 16.56 & 19.78 & 19.7 & 26.8 & 23.3 & 23.33 & 38.61 & 50 \\
\hline 11 & C.O.D $(\mathrm{mg} / \mathrm{L})$ & 268 & 352 & 259 & 220 & 208 & 199 & 115 & 125 \\
\hline 12 & B.O.D(mg/L) & 14.23 & 11.34 & 13.34 & 11.89 & 11.65 & 13.68 & 5.24 & 10 \\
\hline 13 & T.H.C(mg/L) & 1.08 & 0.16 & ND & ND & ND & ND & ND & 0.05 \\
\hline 14 & Sodium(mg/L) & 19.543 & 19.64 & 13.75 & 16.87 & 16.94 & 10.12 & 8.10 & 200 \\
\hline 15 & $\begin{array}{l}\text { Potassium } \\
(\mathrm{mg} / \mathrm{L})\end{array}$ & 9.30 & 8.84 & 12.8 & 13.8 & 9.982 & 9.60 & 5.257 & 2 \\
\hline 16 & $\begin{array}{l}\text { Magnesium } \\
(\mathrm{mg} / \mathrm{L})\end{array}$ & 57.87 & 58.89 & 53.12 & 47.86 & 47.98 & 44.87 & 32.26 & 37 \\
\hline 17 & $\begin{array}{l}\text { Calcium } \\
(\mathrm{mg} / \mathrm{L})\end{array}$ & 61.76 & 57.97 & 53.38 & 56.76 & 59.12 & 53.89 & 43.68 & 50 \\
\hline 18 & $\begin{array}{l}\text { Sulphate } \\
(\mathrm{mg} / \mathrm{L})\end{array}$ & 27.87 & 22.34 & 27.66 & 23.81 & 24.25 & 21.25 & 7.82 & 500 \\
\hline 19 & Nitrate(mg/L) & 1.881 & 1.453 & 1.532 & 1.452 & 1.663 & 0.954 & 13.734 & 1.5 \\
\hline 20 & $\operatorname{Iron}(\mathrm{mg} / \mathrm{L})$ & 1.231 & 2.091 & 0.942 & 0.953 & 1.431 & 1.947 & 0.154 & 1.0 \\
\hline 21 & Copper(mg/L) & 0.981 & 1.143 & 1.003 & 1.214 & 0.349 & 2.015 & 0.98 & 1.0 \\
\hline 22 & Lead(mg/L) & 1.234 & 0.514 & 0.431 & 0.143 & 0.532 & 1.003 & ND & 0.05 \\
\hline 23 & $\begin{array}{l}\text { Chromium } \\
(\mathrm{mg} / \mathrm{L})\end{array}$ & ND & 0.341 & 0.010 & ND & ND & 0.053 & ND & 0.05 \\
\hline 24 & $\begin{array}{l}\text { Cadmium } \\
(\mathrm{mg} / \mathrm{L})\end{array}$ & 0.341 & 0.213 & 0.521 & 0.019 & ND & 0.090 & ND & 0.01 \\
\hline
\end{tabular}

TABLE 3: Anova for Surface Stream Water

\begin{tabular}{|c|c|c|c|c|}
\hline $\begin{array}{ll}\text { Source } & \text { of } \\
\text { variance } & \end{array}$ & SS & Df & Ms & $\mathbf{F}$ \\
\hline Between groups & 13516.20 & 6 & 2252.70 & \multirow[b]{2}{*}{0.31} \\
\hline $\begin{array}{c}\text { Within groups } \\
\text { Total }\end{array}$ & $\begin{array}{l}1083783.87 \\
1097300.07 \\
\end{array}$ & $\begin{array}{l}150 \\
156 \\
\end{array}$ & 7225.23 & \\
\hline $\begin{array}{ll}\text { Source } & \text { of } \\
\text { variance } & \end{array}$ & SS & Df & Ms & $\mathbf{F}$ \\
\hline Between groups & 7860.89 & 6 & 1310.15 & 0.21 \\
\hline $\begin{array}{l}\text { Within groups } \\
\text { Total }\end{array}$ & $\begin{array}{l}932440.31 \\
940301.19\end{array}$ & $\begin{array}{l}149 \\
155\end{array}$ & 6257.99 & \\
\hline
\end{tabular}




\section{CONCLUSION}

The physico-chemical characteristics of the surface and underground water samples obtained at the spill area were observed to be acidic with very low dissolved oxygen, high in chemical and biological oxygen demand, high water hardness, high total dissolved solids and high presence of toxic heavy metals like iron, copper, lead, chromium and cadmium. All these observations are indicators that the water samples are polluted and thus, not suitable for humans and aquatic lives. According to Carla, (2002), it was reported that exposure to crude oil spills causes a variety of health problems. It is therefore highly dangerous to drink from the water at Upenekang spilled site. From the analysis of variance (ANOVA), it was observed that there is no significant influence of distance away from spill on the level of

\section{REFERENCES}

Achi, C. (2003). Hydrocarbon Exploitation, Environmental Degradation and Poverty. The Niger Delta Experience. Paper Presented at the Diffuse Pollution Conference, Dublin.

Ademoroti, C. M. A. (1986). Model to Predict BOD from COD values of Domestic, Poultry and Brewery Wastewaters. Effluent and Water Treatment Journal, 26 (3), 80-84.

Ademoroti, C. M. A. (1996). Standard Methods for Water and Effluents Analysis, Foludex Press Ltd, Ibadan, Nigeria. pp. 36-80.

Akoroda, M. (2000). Remediation Response in the Niger-Delta. Paper Presented at a Seminar to Mark the Anniversary of Jesse fire disaster. Nigerian Institute of International Affairs, Lagos.

America Water Works Association, (1980). Standard Methods for Examination of Water and Wastewater including Bottom Sediment and Sludge. $15^{\text {th }}$ ed., APHA-AWWA- APCF, pp. $148-157$.

Association of Applied Chemist (A.O.A.C), (1984). Methods for Water Analyses for Water Quality. $8^{\text {th }}$ ed. pp. $86-98$.

Carla, W. M. (2002). Environmental Geology. Fifth Edition. McGraw Hill Higher Education, U.S A.308p.

Chindah, I. A. (2000). Environmental Management of Oil Spillage in Niger Delta. History of Oil Exploration.

Damaskos, S. D. and Papadopoulos, A. S. (1983). A General Stochastic Model for predicting Streams. International Journal of Environmental Studies, 21(2), 229- 237.

Ekwere, (2008). Effect of Harmful metals of Crude Oil on aquatic life. Crude Oil Exploration and Exploitation. Current Research Journal of Biological Sciences, 5, pp. 51-52. heavy metals in surface and underground water samples. This observation portends grevious danger as water bodies contaminated with crude oil spills may go unhindered in polluting very large volumes of both surface and underground water resources.

\section{CONTRIBUTIONS OF AUTHORS}

Ndeh, E. S. and Okafor, J. O. carried out the research work and experimental analyses while Akpan, G. U. and Olutoye, M. A. carried out the analysis of variance on the results obtained from the research work.

\section{CONFLICT OF INTEREST}

\section{None}

\section{ACKNOWLEDGEMENT}

We want to acknowledge Petroleum Technology Development Fund (PTDF) for their support all through the course of this research work.

Enujiugha, V. N. and Nwanna, I. C. (2004). Aquatic Oil Impact Indicators. Journal of Applied Sci. Environ. Mgt. Vol. 8(2) 71-75.

Etuk, U. U. (1977). The Impact of Mobil Oil Company on the Economic Life of Eket People. Unpublished B.Sc. Thesis, Department of Sociology. University of Calabar.

Magini, E. J. (2006). Effects of Oil Spillage on Water Quality/ Management in Emadadja, Udu Local Government Area, Delta State, Nigeria. An M.Sc Research Study of Department of Environmental Sciences, Nnamdi Azikiwe University, Awka.

Miguel, G. and Salvador, G. (1998). Strategies for the Rapid Characterization of Metals and Organic Pollutants in Solid Wastes and Contaminated Soils by using Mass Spectrometry. Trends in Analytical Chemistry. 17: 263-272.

Niger Delta Development Commission (NDDC), (2004). Niger Delta Regional Development Master Plan: Draft 3. Director of Planning, NDDC, Port Harcourt, Nigeria.

Osuntokun, A. (1999). Environmental Problems of the Niger Delta. Lagos: Friedrich Ebert Foundation.

Oyeka, C. A. (1996). An Introduction to Applied Statistics, $7^{\text {th }}$ Edition, Nober Avocation Publishing Company, Enugu, pp 218-246.

Oyem, A. (2001). Christian call for action on Nigeria oil spill. Journal of Sage-Oxford's Christian Environmental Group.Vol.1, p.3.

Snowden, R. J. and Ekweozor, I. K. (1987). The Impact of a Minor Oil Spillage in the Estuarine Niger Delta. Marine Pollution Bulletin. Vol. 18, No.11, pp. 23-89.

World Health Organisation, (1993). Guidelines for Drinking Water Quality. $2^{\text {nd }}$ ed. Vol. 1, Recommendations, Geneva. pp. 49-50. 